\title{
Effects of Finish Cooling Temperature on Tensile Properties After Thermal Aging of Strain-Based API X60 Linepipe Steels
}

\author{
HYO KYUNG SUNG, DONG HO LEE, SANG YONG SHIN, SUNGHAK LEE, \\ YUNJO RO, CHANG SUN LEE, and BYOUNGCHUL HWANG
}

Two types of strain-based American Petroleum Institute (API) X60 linepipe steels were fabricated at two finish cooling temperatures, $673 \mathrm{~K}$ and $723 \mathrm{~K}\left(400{ }^{\circ} \mathrm{C}\right.$ and $\left.450{ }^{\circ} \mathrm{C}\right)$, and the effects of the finish cooling temperatures on the tensile properties after thermal aging were investigated. The strain-based API X60 linepipe steels consisted mainly of polygonal ferrite (PF) or quasipolygonal ferrite and the volume fraction of acicular ferrite increased with the increasing finish cooling temperature. In contrast, the volume fractions of bainitic ferrite (BF) and secondary phases decreased. The tensile properties before and after thermal aging at $473 \mathrm{~K}$ and $523 \mathrm{~K}$ $\left(200{ }^{\circ} \mathrm{C}\right.$ and $\left.250{ }^{\circ} \mathrm{C}\right)$ were measured. The yield strength, ultimate tensile strength, and yield ratio increased with the increasing thermal aging temperature. The strain hardening rate in the steel fabricated at the higher finish cooling temperature decreased rapidly after thermal aging, probably due to the Cottrell atmosphere, whereas the strain hardening rate in the steel fabricated at the lower finish cooling temperature changed slightly after thermal aging. The uniform elongation and total elongation decreased with increasing thermal aging temperature, probably due to the interactions between carbon atoms and dislocations. The uniform elongation decreased rapidly with the decreasing volume fractions of BF and martensite and secondary phases. The yield ratio increased with the increasing thermal aging temperature, whereas the strain hardening exponent decreased. The strain hardening exponent of PL steel decreased rapidly after thermal aging because of the large number of mobile dislocations between PF and $\mathrm{BF}$ or martensite or secondary phases.

DOI: $10.1007 / \mathrm{s} 11661-015-2984-3$

(C) The Minerals, Metals \& Materials Society and ASM International 2015

\section{INTRODUCTION}

STRUCTURAL steels with high strength and high toughness are needed to establish stable and safe constructions of large buildings, industrial facilities, bridges, and ships. In particular, the recently developed API linepipe steels need to have high formability as well as high strength and high toughness to improve the fracture resistance to sudden deformation and fractures caused by heavy storms, earthquakes, and seismic sea waves. Therefore, a range of linepipe steels have been studied to improve the mechanical properties. ${ }^{[1,2]}$ In particular,

HYO KYUNG SUNG, Postdoctoral Research Associate, is with the Division of Engineering, Brown University, Providence, RI 02912. DONG HO LEE, Research Assistant, and SUNGHAK LEE, Professor, are with the Center for Advanced Aerospace Materials, Pohang University of Science and Technology, Pohang 790-784, Korea. SANG YONG SHIN, Assistant Professor, is with the School of Materials Science and Engineering, University of Ulsan, Ulsan 680-749, Korea. Contact e-mail: sshin@ulsan.ac.kr YUNJO RO, Research, and CHANG SUN LEE, Senior Vice President, are with the POSCOA Research Group Team, Technical Research Laboratories, POSCO, Gwangyang 545-878, Korea. BYOUNGCHUL HWANG, Assistant Professor, is with the Department of Materials Science and Engineering, Seoul National University of Science and Technology, Seoul 139-743, Korea.

Manuscript submitted February 2, 2015.

Article published online June 2, 2015 the uniform elongation of the linepipe steels are reduced during the coating process to prevent corrosion after the piping processes. ${ }^{[3,4]}$ The epoxy coating temperature range of linepipe steels is $473 \mathrm{~K}$ to $573 \mathrm{~K}\left(200{ }^{\circ} \mathrm{C}\right.$ to $300{ }^{\circ} \mathrm{C}$ ), at which the Cottrell atmosphere occurs. ${ }^{[5]}$ In the Cottrell atmosphere, the decrease in uniform elongation is caused by the interactions between the carbon atoms in ferrite and dislocations, which results in yield point phenomena during the tensile tests. ${ }^{[5,6]}$ Many studies have been conducted to form large amounts of cementite in linepipe steels and to reduce the number of carbon atoms in ferrite because carbon atoms are the main factors for the strain aging phenomena. ${ }^{[7-12]}$ The finish cooling temperatures strongly affect the formation of secondary phases, such as cementite and martensite-austenite constituents (MA). ${ }^{[13]}$

The microstructures of linepipe steels are dependent on their chemical compositions and cooling and rolling conditions, and are classified according to the morphological categories. ${ }^{[14-16]}$ Polygonal ferrite (PF) is formed at high temperatures and a slow cooling rate, and has an equi-axed shape nucleated from prior austenite grain boundaries and very low dislocation density. Ferrite grains become more irregularly shaped with the decreasing transformation temperature or increasing total plastic deformation performed by hot rolling processes, in which the ferrite is called quasi-polygonal ferrite 
(QPF). Acicular ferrite (AF) has an excellent combination of strength and toughness because its grains are fine (several micrometers in size), irregularly shaped and aligned in arbitrary directions. Bainitic ferrite (BF) is generally formed at rapid cooling rates, and has high strength and low toughness owing to its lath-type microstructure. Martensite or martensite-austenite constituents are formed finely in the regions with a high carbon content.

Shigesato et al. ${ }^{[5]}$ reported the effects of the finish cooling temperatures on the microstructure and carbide formation mechanisms of strain-based linepipe steels. Strain-based steels mean steels suitable for strain-based design. Ferrite is formed at temperatures between $\mathrm{Ar}_{3}$ temperature and $B_{\mathrm{s}}$ temperature, in which carbon atoms in ferrite move to austenite and form $\mathrm{Ti}$ and $\mathrm{Nb}$ carbides because of the lower carbon solubility in ferrite than in austenite. During the formation of bainite below the $\mathrm{B}_{\mathrm{s}}$ temperature, carbon atoms do not form $\mathrm{Ti}$ and $\mathrm{Nb}$ carbides but form cementites due to the low carbon mobility by the shear transformation behavior rather than by the diffusion behavior. If the finish cooling temperature is quite low, carbon atoms do not form cementites but instead form martensites due to the very low carbon mobility.

Conventional strain-based API X60 linepipe steels consist mainly of PF. ${ }^{[17]}$ These strain-based linepipe steels show discontinuous yielding behavior during the tensile test, because the volume fraction of low-temperature transformation phases is low such as bainite, martensite, and secondary phases with a high dislocation density. ${ }^{[18]}$ For continuous yielding behaviors to occur during tensile tests, low-temperature transformation microstructures, such as AF and $\mathrm{BF}$ with fine grain size, should be distributed evenly. ${ }^{[5,9,19]}$ Ishikawa et $a l .{ }^{[19]}$ reported that strain-based linepipe steels consisting of PF with a small amount of BF have high uniform elongation when the volume fraction of $\mathrm{BF}$ is 20 to $40 \mathrm{vol}$ pct, whereas the yield ratio is low. The strengths increase and continuous yielding behavior occurs with the increasing volume fraction of BF. Hara et al. ${ }^{[9]}$ reported that strain-based linepipe steels with $\mathrm{Cr}$, which is a strong carbide forming element, exhibited continuous yielding behaviors without large reduction of the uniform elongation. In the cases of API X80 and X100 linepipe steels consisting mainly of bainite, Shigesato et al. ${ }^{[5]}$ reported that the uniform elongation increases with the increasing volume fraction of $\mathrm{PF}$ formed by mild accelerated cooling conditions. Because the microstructure of strain-based API X60 linepipe steels consists of $\mathrm{PF}, \mathrm{AF}, \mathrm{BF}$, and $\mathrm{MA}$, it is important to optimize the microstructural factors of the steels for high uniform elongation after thermal aging.

This study examined the microstructure of the strainbased API X60 linepipe steels for high uniform elongation after the thermal aging processes by the varying finish cooling temperatures. Two types of strain-based API X60 linepipe steels were fabricated by varying the finish cooling temperatures, and their microstructures were analyzed. Moreover, the effective grains and grain boundary conditions, such as low- or high-angle grain boundaries, were analyzed by electron backscatter diffraction (EBSD). The tensile properties, such as the strength and uniform elongation, were investigated by tensile tests before and after the thermal aging process. The Charpy impact test and drop weight tear test (DWTT) were performed at room temperature and low temperatures to measure the impact toughness properties, from which the effects of the finish cooling temperatures on mechanical properties were investigated.

\section{EXPERIMENTAL}

The chemical composition of the strain-based API X60 linepipe steels was $0.05 \mathrm{C}-0.15 \mathrm{Si}-1.5 \mathrm{Mn}-$ $0.015(\mathrm{P}+\mathrm{S})-0.35(\mathrm{Ni}+\mathrm{Cr}+\mathrm{Al}+\mathrm{Ti}+\mathrm{Nb})$ (wt pct) and the cooling conditions after rolling processes are shown in Figure 1. All steels were austenized at $1373 \mathrm{~K}$ $\left(1100{ }^{\circ} \mathrm{C}\right)$ for 2 hours and then rolled in the austenite region ( $\gamma$ region) under air-cooling conditions, in which the reduction ratio of 89 pct was given to make a steel plate with a final thickness of $32 \mathrm{~mm}$. After finish rolling above the $\mathrm{Ar}_{3}$ temperature of $1043 \mathrm{~K}\left(770{ }^{\circ} \mathrm{C}\right)$, the sample was water-cooled at a cooling rate of $30 \mathrm{~K} \mathrm{~s}^{-1}$ until $673 \mathrm{~K}$ or $723 \mathrm{~K}\left(400{ }^{\circ} \mathrm{C}\right.$ or $\left.450{ }^{\circ} \mathrm{C}\right)$, and then aircooled to room temperature. For convenience, the strain-based API X60 linepipe steels that were watercooled until $673 \mathrm{~K}$ and $723 \mathrm{~K}\left(400{ }^{\circ} \mathrm{C}\right.$ and $\left.450{ }^{\circ} \mathrm{C}\right)$ are referred as 'PL' and 'PH' steels, respectively.

The steel specimens obtained from the $1 / 4$ thickness location of the rolled plates were polished and etched in a 2 pet nital solution and microstructures of longitudinal-transverse $(\mathrm{L}-\mathrm{T})$ planes were observed by optical and scanning electron microscope (SEM, model; S4300E, Hitachi, Tokyo, Japan). For electron backscatter diffraction analysis, the steel specimens were polished using a colloidal silica solution after mechanical polishing. EBSD (resolution: $400 \mathrm{~nm}$ ) was conducted using a field emission scanning electron microscope (FE-SEM, model: S-4300SE, Hitachi, Tokyo, Japan). The data were then interpreted using the orientation imaging microscopy analysis software provided by TexSEM Laboratories, Inc.

Large-scale tensile specimens were obtained from the $1 / 4$ thickness location of the rolled plates and used to apply a pre-strain of 2 pct, see Figure 2. Plate-type large-scale tensile specimens with a gage length of $200 \mathrm{~mm}$, a width of $80 \mathrm{~mm}$, and a thickness of $10 \mathrm{~mm}$ were prepared in the transverse direction. A pre-strain of 2 pct was given on the large-scale tensile specimens to simulate the strain state of the piping process. ${ }^{[3]}$ The tensile tests were performed on the large-scale tensile specimens at room temperature at a strain rate of $0.003 \mathrm{~s}^{-1}$ using an Instron machine (model; 5567, Instron, Canton, MA, USA) with a $100 \mathrm{kN}$ capacity. Heat treatment at $473 \mathrm{~K}$ and $523 \mathrm{~K}\left(200{ }^{\circ} \mathrm{C}\right.$ and $\left.250{ }^{\circ} \mathrm{C}\right)$ for 5 minutes was performed on the pre-strained largescale tensile specimens to simulate the epoxy coating process. The specimens were held at temperatures for 5 minutes. Round-type small-scale tensile specimens were obtained from the pre-strained large-scale tensile specimens that had been prepared with a gage length of $25.4 \mathrm{~mm}$ and a diameter of $4.8 \mathrm{~mm}$. In this process, the 


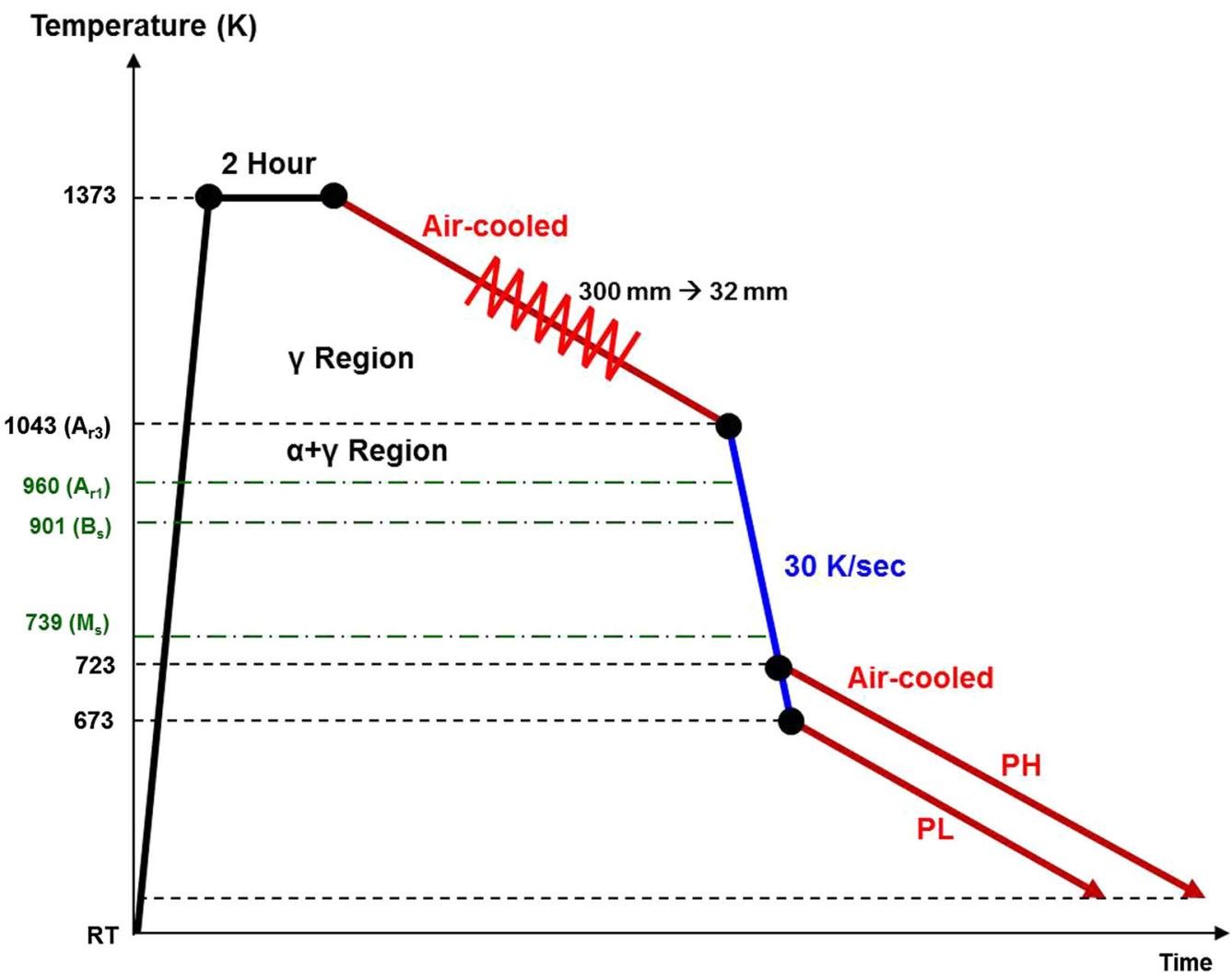

Fig. 1-Schematic diagram of the rolling and cooling conditions of the strain-based API X60 linepipe steels.

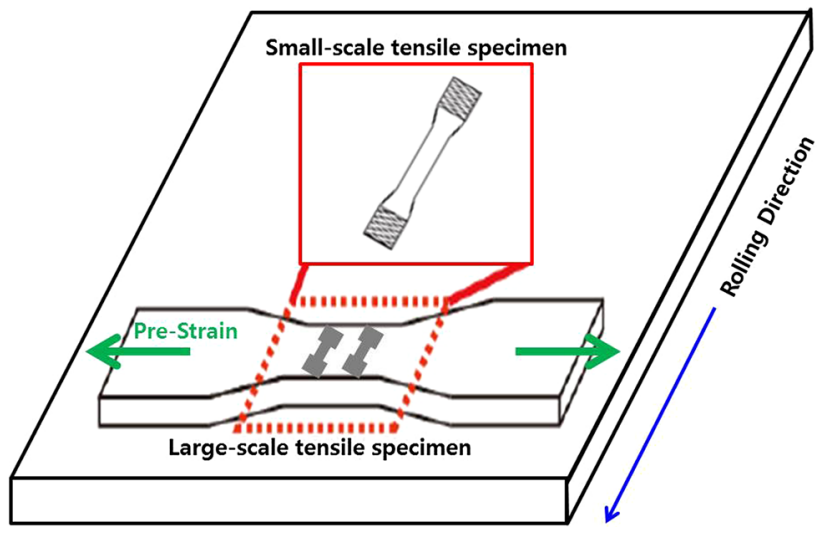

Fig. 2-Schematic diagram showing how to prepare the large-scale tensile specimens for the pre-strain test and the tensile specimens for the tensile test after thermal aging processes. ${ }^{[3]}$

90 deg change in the direction of tensile specimens well simulated the actual situation inside the linepipe steel plates during the piping processes. ${ }^{[3,20]}$ Tensile tests were performed on small-scale tensile specimens at room temperature at a strain rate of $0.003 \mathrm{~s}^{-1}$ using an Instron machine (model; 5567, Instron, USA) with a $100 \mathrm{kN}$ capacity. From the stress-strain curves, the tensile properties, such as the yield strength, ultimate tensile strength, uniform elongation, yield ratio, and continuous yielding or discontinuous yielding behavior, were measured.
The DWTT specimens were obtained from the rolled plates according to the API RP 5L3 specifications. The DWTT specimen was $76.2 \times 305 \times 25 \mathrm{~mm}^{3}$ in size in the transverse-longitudinal $(\mathrm{T}-\mathrm{L})$ direction, and a pressed notch was then introduced. ${ }^{[21]}$ The DWTT specimens were tested at $253 \mathrm{~K}\left(-20^{\circ} \mathrm{C}\right)$ (test temperature recommended by the API) using a DWTT testing machine (model: DWTT-100, Imatek, UK) with a $100 \mathrm{~kJ}$ capacity. According to the ASTM E23, the Charpy impact tests were performed on standard Charpy V-notch specimens obtained from the $1 / 4$ thickness location of the rolled plates (size; $10 \times 10 \times 55 \mathrm{~mm}^{3}$, orientation; transverse-longitudinal $(\mathrm{T}-\mathrm{L}))$ at temperatures from $133 \mathrm{~K}$ to $273 \mathrm{~K}$ $\left(-140{ }^{\circ} \mathrm{C}\right.$ to $\left.0{ }^{\circ} \mathrm{C}\right)$ using a Tinius Olsen impact tester (model: FAHC-J-500-01, JT Toshi, Tokyo, Japan) with a $500 \mathrm{~J}$ capacity. ${ }^{[22]}$

\section{RESULTS}

\section{A. Microstructures}

Figures 2 and 3 show optical and SEM images of the steel samples, from which the volume fractions of the microstructures were measured, as listed in Table I. Four SEM micrographs at a magnification of 3000 were analyzed for each steel sample, and the volume fractions of the microstructures were obtained using an image analyzer program (Sigma scan pro, Systat Software Inc., USA). The total examined area was approximately 

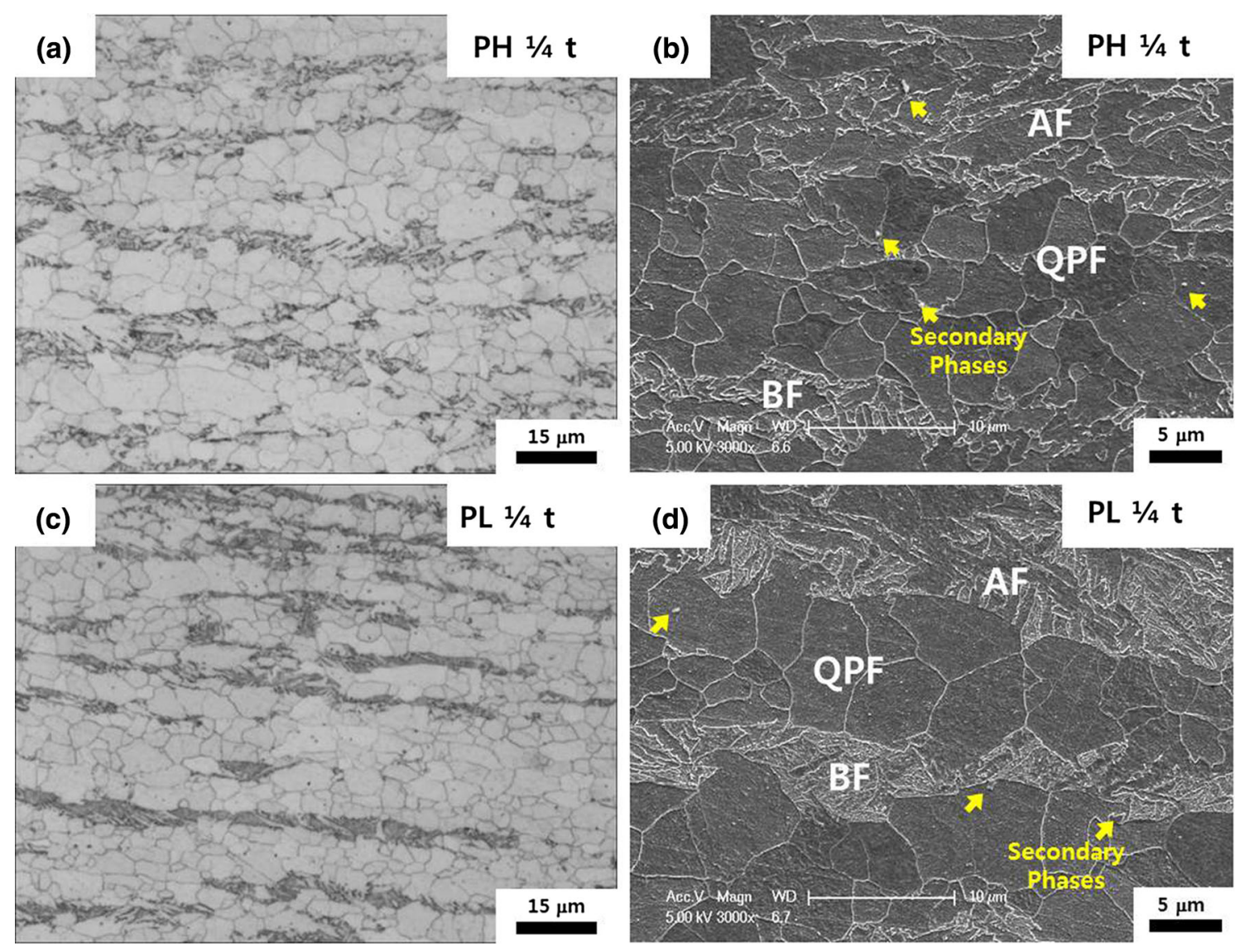

Fig. 3-Optical and SEM images (L-T plane) of the nital etched (a) and (b) PH steel, and (c) and (d) PL steel.

Table I. Volume Fractions of Polygonal Ferrite (PF) or Quasi-Polygonal Ferrite (QPF), Acicular Ferrite (AF), Bainitic Ferrite (BF), and Martensite and Secondary Phases in the Strain-Based API X60 Linepipe Steels

\begin{tabular}{llrrr}
\hline & \multicolumn{3}{c}{ Volume Fraction (Pct) } \\
\cline { 2 - 5 } Steels & PF or QPF & \multicolumn{1}{c}{ AF } & BF & Martensite and Secondary Phases* \\
\hline PH & bal. & $18.6 \pm 2.3$ & $4.9 \pm 1.1$ & $1.3 \pm 0.3$ \\
PL & & $3.5 \pm 1.2$ & $23.8 \pm 2.7$ & $2.1 \pm 0.5$ \\
\hline
\end{tabular}

*Secondary phases include martensite-austenite constituents and cementite.

$5080 \mu \mathrm{m}^{2}(=4$ ea. $\times 41 \mu \mathrm{m} \times 31 \mu \mathrm{m})$. The microstructures of linepipe steels are classified according to the morphological categories. ${ }^{[14-16]}$ Fine martensite and secondary phases were difficult to distinguish, so the volume fraction of fine martensite and secondary phases was measured together. The main microstructures in the steels were PF and QPF and the volume fractions of the microstructures were varied by the finish cooling temperatures. In the PH steel with the higher finish cooling temperature, the volume fraction of $\mathrm{AF}$ was high (18.6 vol pct), whereas the volume fractions of $\mathrm{BF}$ and martensite and secondary phases were low (4.9 and 1.3 vol pct, respectively). In the PL steel with the lower finish cooling temperature, however, the volume fraction of AF was low (3.5 vol pct), whereas the volume fractions of $\mathrm{BF}$ and martensite and secondary phases were high (23.8 and $2.1 \mathrm{vol}$ pct, respectively).
Figure 4 shows the image quality maps, inverse pole figure maps, and Kernel average misorientation (KAM) maps of the steels analyzed by EBSD. To analyze the KAM maps, each of the second nearest neighbor points was calculated and the threshold value was $5 \mathrm{deg}$. In the image quality maps, the grain boundaries of QPFs were $\geq 15 \mathrm{deg}$, whereas the subgrain boundaries of BFs were $\leq 15 \mathrm{deg}$. In the inverse pole figure maps of the PL steel, the regions with $\mathrm{BFs}$ had a coarse grain size. In the KAM maps of the PL steel, the local misorientation values in the regions with BFs were higher than those in the regions with the QPFs because the subgrain boundaries of BFs were $\leq 15 \mathrm{deg}$ and the BFs had higher dislocation densities than the QPFs.

Figure 5 shows a high-magnification image quality and KAM maps of the steels. The regions with BFs were highly misorientated areas in the KAM maps because BF consists 


\begin{tabular}{|c|c|c|c|c|c|}
\hline \multicolumn{3}{|c|}{ (a) $\mathrm{PH}$} & \multicolumn{3}{|c|}{ (b) PL } \\
\hline 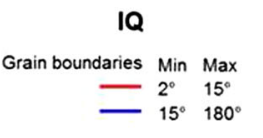 & $\begin{array}{c}\text { IPF } \\
\text { Grain boundaries } \\
-\quad \text { Min Max } \\
-15^{\circ} 180^{\circ}\end{array}$ & 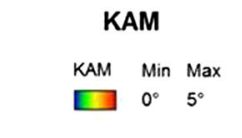 & 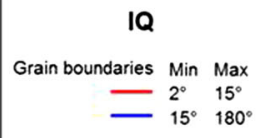 & $\begin{array}{r}\text { IPF } \\
\text { Grain boundaries } \\
-\begin{array}{c}\text { Min } \\
-15^{\circ} 180^{\circ}\end{array} \\
\end{array}$ & 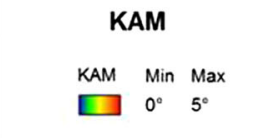 \\
\hline 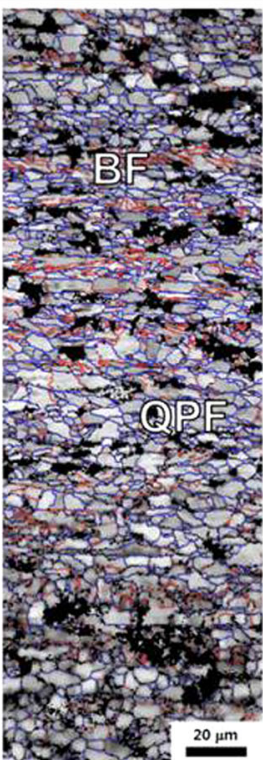 & 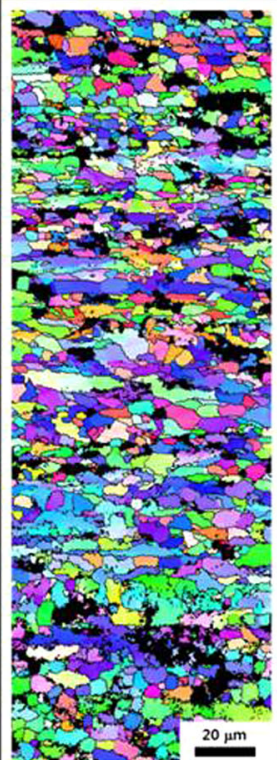 & $\frac{-4}{2+3}$ & 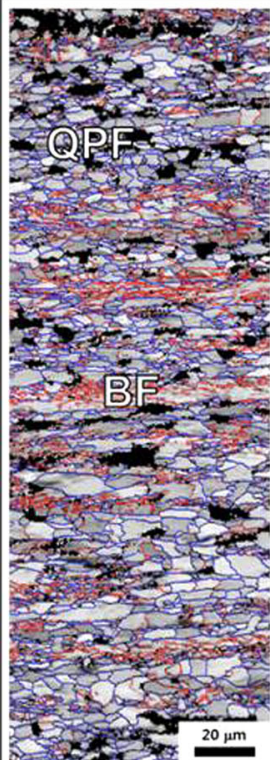 & 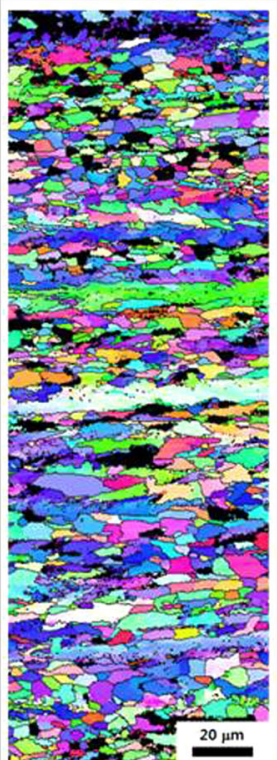 & 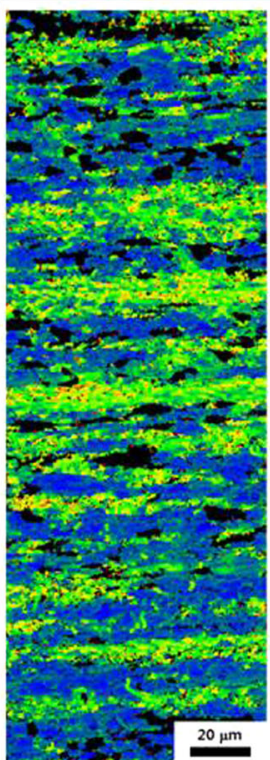 \\
\hline
\end{tabular}

Fig. 4-Image quality, inverse pole figure, and kernel average misorientation maps of the (a) PH and (b) PL steels.

of many sub-grains and has a high dislocation density. A large number of mobile dislocations can be generated near the areas between BF and PF during the tensile test; hence continuous yielding behavior occurs. ${ }^{[13,23]}$

The strain-based API X60 linepipe steels consisting of $\mathrm{PF}$ were reported to have high elongation, and the steels with large amounts of BF and martensite and secondary phases showed good uniform elongation after thermal aging.${ }^{[5,9,19]}$ In this study, the finish cooling temperatures were varied to form a large amount of $\mathrm{BF}$ and martensite and secondary phases. The formations of bainite and martensite are affected by the cooling process. According to Capdevila et al. ${ }^{[24]}$ Andrew et al., ${ }^{[25]}$ and Kung et al., ${ }^{[26]}$ the bainite start $\left(B_{\mathrm{s}}\right)$ temperature and martensite start $\left(M_{\mathrm{S}}\right)$ temperature can be calculated using the following two equations:

$$
\begin{gathered}
B_{\mathrm{s}}\left({ }^{\circ} \mathrm{C}\right)=745-110 \mathrm{C}-59 \mathrm{Mn}-39 \mathrm{Ni}-68 \mathrm{Cr} \\
-106 \mathrm{Mo}-17 \mathrm{MnNi}+6 \mathrm{Cr}^{2}+29 \mathrm{Mo}^{2} \\
M_{\mathrm{s}}\left({ }^{\circ} \mathrm{C}\right)=539-423 \mathrm{C}-30.4 \mathrm{Mn}-12.1 \mathrm{Cr} \\
-17.7 \mathrm{Ni}-7.5 \mathrm{Mo}+10 \mathrm{Co}
\end{gathered}
$$

The calculated $B_{\mathrm{s}}$ and $M_{\mathrm{s}}$ temperatures of the strainbased API X60 steels used in this study were $901 \mathrm{~K}$ and $739 \mathrm{~K}\left(628{ }^{\circ} \mathrm{C}\right.$ and $\left.466{ }^{\circ} \mathrm{C}\right)$, respectively. BF or martensite or secondary phases were formed below the $\mathrm{Ar}_{3}$ temperature of $1043 \mathrm{~K}\left(770{ }^{\circ} \mathrm{C}\right)$ at a cooling rate of $30 \mathrm{~K} \mathrm{~s}^{-1}$. The volume fraction of $\mathrm{BF}$ in the $\mathrm{PH}$ steel with the higher finish cooling temperature of $723 \mathrm{~K}\left(450{ }^{\circ} \mathrm{C}\right)$ was low because of the low degree of undercooling $\left(=\left[\begin{array}{ll}B_{\mathrm{s}} & \text { temperature }]\end{array}-[\right.\right.$ finish cooling temperature $\left.]\right)$, whereas the volume fraction of $\mathrm{BF}$ in the PL steel with the lower finish cooling temperature of $673 \mathrm{~K}\left(400{ }^{\circ} \mathrm{C}\right)$ was high because of the high degree of undercooling. The volume fractions of martensite were affected by the degree of cooling. Koistinen et al. ${ }^{[27]}$ calculated the amount of martensite using the following equation:

$$
M_{\mathrm{f}}=1-\exp \left\{-\left(1.10 \times 10^{-2} \Delta T\right)\right\},
$$

where $\Delta T$ is the degree of cooling $\left(=\left[M_{\mathrm{s}}\right.\right.$ temperature] - [finish cooling temperature]). The volume fraction of martensite increases with the increasing $\Delta T$. Although the finish cooling temperature of the steels were lower than $M_{\mathrm{s}}$ temperature $\left[739 \mathrm{~K}\left(466{ }^{\circ} \mathrm{C}\right)\right]$, a little amount of fine martensites formed because of an experimental error of the finish cooling temperature and empirical equations. Fine martensite and secondary phases were difficult to distinguish, so the volume fraction of fine martensite and secondary phases was measured together. The volume fraction of martensite and secondary phases in the PL steel is higher than that in PH steel, in which the PL steel had a lower finish cooling temperature than the PH steel. In other words, PL steel had a larger degree of cooling than the PH steel.

\section{B. Mechanical Properties}

Figure 6 shows the room temperature stress-strain curves of the steels, from which the yield strength, 


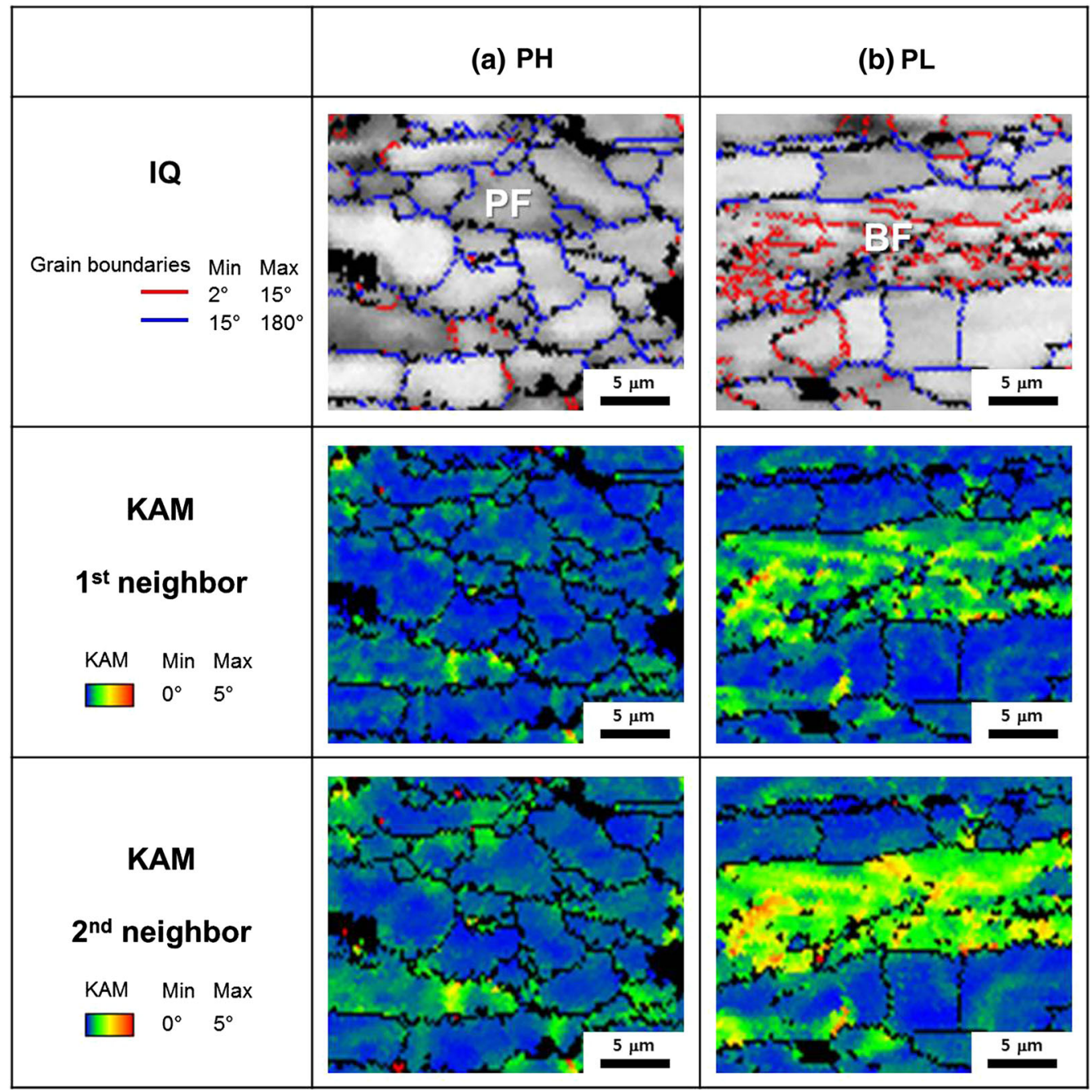

Fig. 5-High-magnification image quality and kernel average misorientation maps of the (a) PH and (b) PL steels.

ultimate tensile strength, uniform elongation, total elongation, and yield ratio values were measured, as shown in Table II. All the tensile curves of the steels showed continuous yielding behaviors. From the tensile properties of the steels before the thermal aging processes, the yield strength was 430 and $438 \mathrm{MPa}$, respectively, which satisfied the requirement of the API X60 strength level. The yield strength, ultimate tensile strength, and yield ratio increased after thermal aging at $473 \mathrm{~K}$ and $523 \mathrm{~K}\left(200{ }^{\circ} \mathrm{C}\right.$ and $\left.250{ }^{\circ} \mathrm{C}\right)$, and the values increased with the increasing thermal aging temperature, whereas the uniform elongation and total elongation decreased with the increasing thermal aging temperature. The decrease in the uniform elongation of the $\mathrm{PH}$ steel before and after thermal aging was large (4 to $4.5 \mathrm{pct}$ ), whereas the decrease in the uniform elongation of the PL steel before and after the thermal aging processes was small (1.4 to $2.5 \mathrm{pct}$ ). Figure 7 shows the true stress-true strain curves and strain hardening rate curves obtained from the room temperature tensile test of the steels before and after thermal aging at $473 \mathrm{~K}$ and $523 \mathrm{~K}\left(200{ }^{\circ} \mathrm{C}\right.$ and $\left.250{ }^{\circ} \mathrm{C}\right)$. Figure 8 shows the uniform elongation, the yield ratio, and the strain hardening exponent as a function of the thermal aging temperature.

After the DWTT, the fracture surfaces were observed by SEM, and the area fractions of shear appearance were measured using an image analyzer. Figure 9 shows the fracture surfaces of the DWTT specimens fractured at $253 \mathrm{~K}\left(-20^{\circ} \mathrm{C}\right)$. The fracture surfaces of the DWTT specimens were 100 pct ductile fracture surfaces, which resulted from the main microstructure of $\mathrm{PF}$ with good toughness and a small grain sizes due to the high reduction ratio of 89 pct. Figure 10 shows the Charpy absorbed energy as a function of the temperature and Table III lists the Charpy absorbed energies. The Charpy absorbed energies at $273 \mathrm{~K}\left(0{ }^{\circ} \mathrm{C}\right)$ of the two steels were high at $450 \mathrm{~J}$ and the ductile brittle transition temperatures of the steels were low at below $153 \mathrm{~K}\left(-120^{\circ} \mathrm{C}\right)$, which results in high toughness at low temperatures. 


\section{DISCUSSION}

The strain-based API X60 linepipe steels consisted mainly of PF or QPF and the volume fraction of AF increased with the increasing finish cooling temperature, whereas the volume fractions of $\mathrm{BF}$ and martensite and secondary phases decreased. The PH steel with the low volume fractions of BF and martensite and secondary phases would have higher carbon content in ferrite than

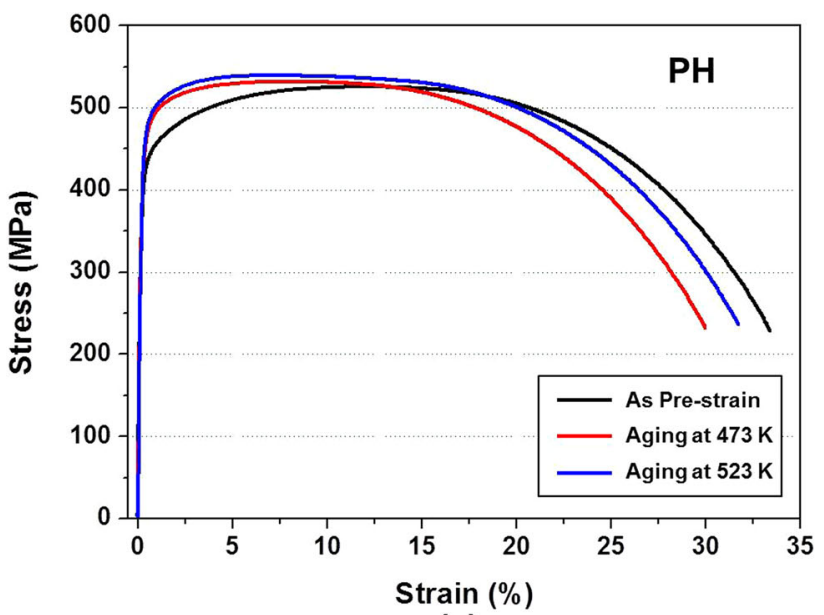

(a)

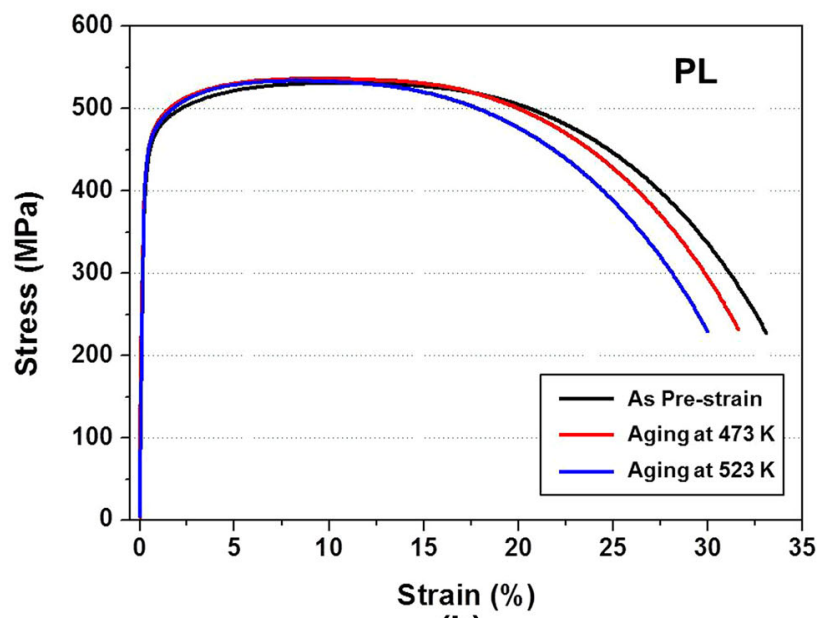

(b)

Fig. 6-Engineering stress-engineering strain curves obtained from the room temperature tensile test of the $(a) \mathrm{PH}$ and (b) PL steel sample before and after thermal aging at $473 \mathrm{~K}$ and $523 \mathrm{~K}\left(200{ }^{\circ} \mathrm{C}\right.$ and $\left.250{ }^{\circ} \mathrm{C}\right)$. the PL steel with the high volume fractions of $\mathrm{BF}$ and martensite and secondary phases. These carbon atoms in ferrite interact with dislocations during the thermal aging, i.e., the Cottrell atmosphere; hence the interactions affect tensile properties. In Figure 7, the PH steel before thermal aging showed a gradual decrease in the strain hardening rate, whereas the $\mathrm{PH}$ steels after thermal aging showed a sharp decrease in the strain hardening rate. In the $\mathrm{PH}$ steel with the low volume fractions of $\mathrm{BF}$ and martensite and secondary phases,

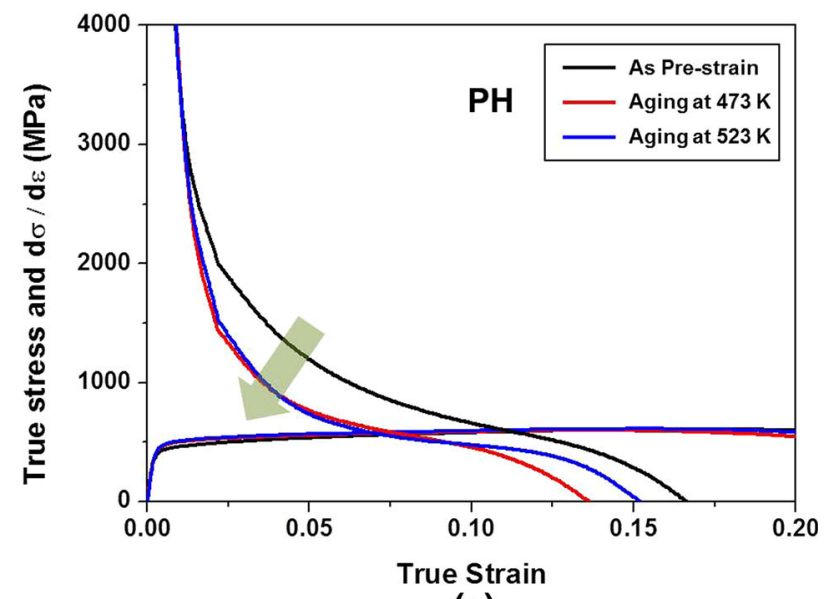

(a)

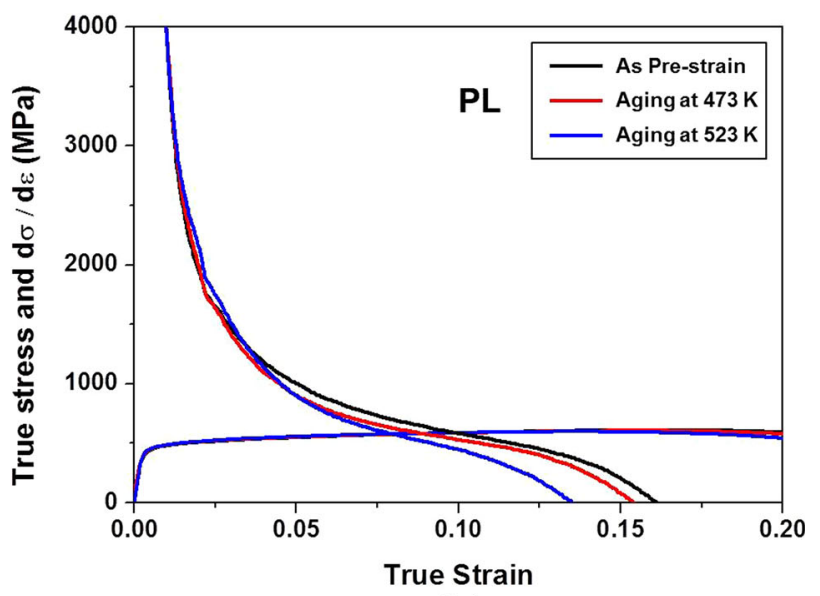

(b)

Fig. 7-True stress-true strain and strain hardening rate curves obtained from the room temperature tensile test of the $(a) \mathrm{PH}$ and $(b)$ PL steel samples before and after thermal aging processes at $473 \mathrm{~K}$ and $523 \mathrm{~K}\left(200{ }^{\circ} \mathrm{C}\right.$ and $\left.250{ }^{\circ} \mathrm{C}\right)$.

Table II. Room Temperature Tensile Properties of the Steels Before and after Aging

\begin{tabular}{|c|c|c|c|c|c|c|}
\hline Steels & $\begin{array}{c}\text { Aging } \\
\text { Temperature }\end{array}$ & $\begin{array}{c}\text { Yield } \\
\text { Strength (MPa) }\end{array}$ & $\begin{array}{l}\text { Ultimate Tensile } \\
\text { Strength (Mpa) }\end{array}$ & $\begin{array}{l}\text { Uniform Elongation } \\
\text { (Pct) }\end{array}$ & $\begin{array}{l}\text { Total Elongation } \\
\text { (Pct) }\end{array}$ & $\begin{array}{l}\text { Yield } \\
\text { Ratio }\end{array}$ \\
\hline \multirow[t]{3}{*}{$\mathrm{PH}$} & as pre-strain & $430 \pm 3.5$ & $526 \pm 5.2$ & $11.9 \pm 0.4$ & $33 \pm 0.9$ & 0.82 \\
\hline & $473 \mathrm{~K}\left(200^{\circ} \mathrm{C}\right)$ & $465 \pm 2.8$ & $532 \pm 3.3$ & $7.9 \pm 0.2$ & $30 \pm 0.6$ & 0.87 \\
\hline & $523 \mathrm{~K}\left(250^{\circ} \mathrm{C}\right)$ & $473 \pm 3.9$ & $538 \pm 4.4$ & $7.4 \pm 0.3$ & $32 \pm 0.7$ & 0.88 \\
\hline \multirow[t]{3}{*}{ PL } & as pre-strain & $438 \pm 1.6$ & $532 \pm 2.3$ & $10.8 \pm 0.4$ & $33 \pm 0.8$ & 0.82 \\
\hline & $473 \mathrm{~K}\left(200^{\circ} \mathrm{C}\right)$ & $448 \pm 3.4$ & $535 \pm 4.6$ & $9.4 \pm 0.2$ & $32 \pm 0.5$ & 0.84 \\
\hline & $523 \mathrm{~K}\left(250^{\circ} \mathrm{C}\right)$ & $454 \pm 2.7$ & $535 \pm 3.8$ & $8.3 \pm 0.3$ & $31 \pm 0.6$ & 0.85 \\
\hline
\end{tabular}




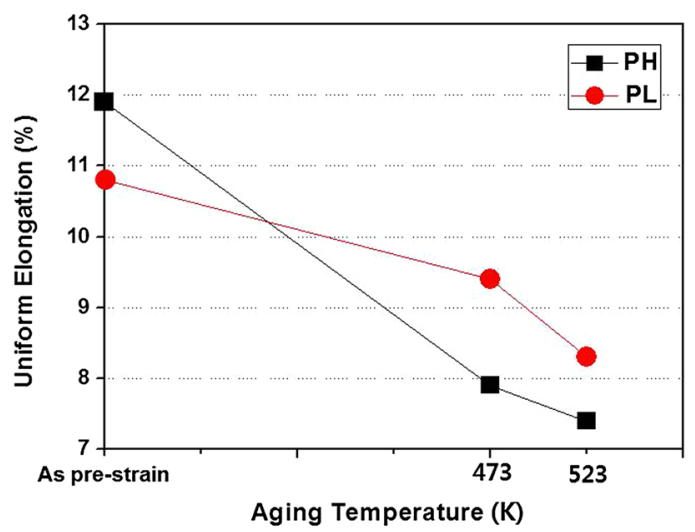

(a)

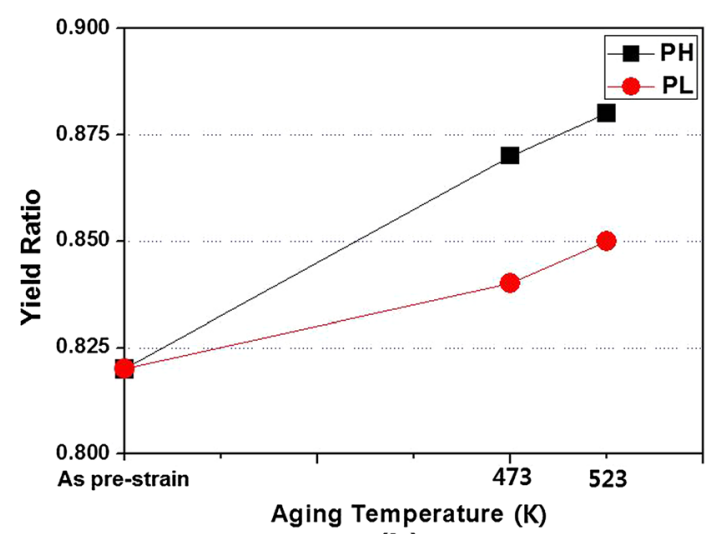

(b)

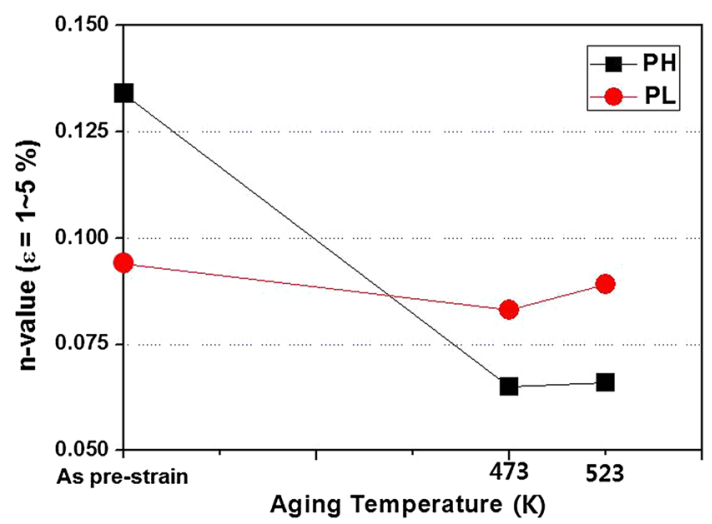

(c)

Fig. 8-(a) Uniform elongation, (b) yield ratio, and (c) $n$-value of the PH and PL steels as a function of the thermal aging temperature.

the dislocation hardening mechanism does not work probably because of the high carbon content in ferrite and the interactions between the carbon atoms and dislocations, i.e., the Cottrell atmosphere. On the other hand, the decrease in the strain hardening rate of the PL steel before and after thermal aging was similar, i.e., the strain aging was similar in the PL steel before and after thermal aging because the carbon content in ferrite is low and the volume fractions of $\mathrm{BF}$ and martensite and secondary phases are high.

In Figure 8, before thermal aging, the uniform elongation of the $\mathrm{PH}$ steel with the high volume fractions of PF and AF was high (12 vol pct), whereas the uniform elongation of the PL steel with high volume fractions of $\mathrm{BF}$ and martensite and secondary phases was low (11 vol pct). The uniform elongation of the steels decreased after thermal aging probably because the carbon atoms in ferrite move out and interact with the dislocations, i.e., the Cottrell atmosphere. The decrease in the uniform elongation of the $\mathrm{PH}$ steel was high at 4 to 4.5 pct because of the low volume fractions of BF and martensite and secondary phases, whereas the decrease in the uniform elongation of the PL steel was low because of the high volume fractions of $\mathrm{BF}$ and martensite and secondary phases and the many mobile dislocations generated between ferrite and $\mathrm{BF}$ or secondary phases. The yield ratios of the steel samples before thermal aging were the same and the yield ratio after thermal aging increased with the increasing thermal aging temperature. The increase in the yield ratio of the PH steel was higher than that in the PL steel. In the PL steel, however, the strain hardening exponent decreased after thermal aging probably because of the large number of mobile dislocations between $\mathrm{PF}$ and $\mathrm{BF}$ or secondary phases.

Nagai et al.$^{[3]}$ reported that discontinuous yielding behaviors occur in the API X80 linepipe steels. In addition, the uniform elongation decreases and the strain hardening exponent increases after thermal aging. In this study, however, the strain hardening exponent decreased with the decreasing uniform elongation because continuous yielding behavior occurs after thermal aging. The yielding behaviors strongly affect the strain hardening exponent. Kim et al. ${ }^{[28]}$ reported that the strain hardening exponent decreases with the increasing dislocation density. In this study, all the tensile specimens showed continuous yielding behaviors due to the high mobile dislocation densities; hence the strain hardening exponent decreases after thermal aging. The degree of the decrease in the uniform elongation of the PL steel was lower than that of the PH steel because the volume fraction of $\mathrm{BF}$ in the PL steel was higher than that in the PH steel. These results showed that it is important to achieve evenly distributed fine-sized BF and martensite and secondary phases in the main microstructure of PF to develop the strain-based API X60 linepipe steels with high uniform elongation after thermal aging.

\section{CONCLUSIONS}

Two types of strain-based API X60 linepipe steels were fabricated by varying the finish cooling temperatures, and their microstructures were analyzed to examine the effects of the finish cooling temperatures on the tensile properties after thermal aging. 

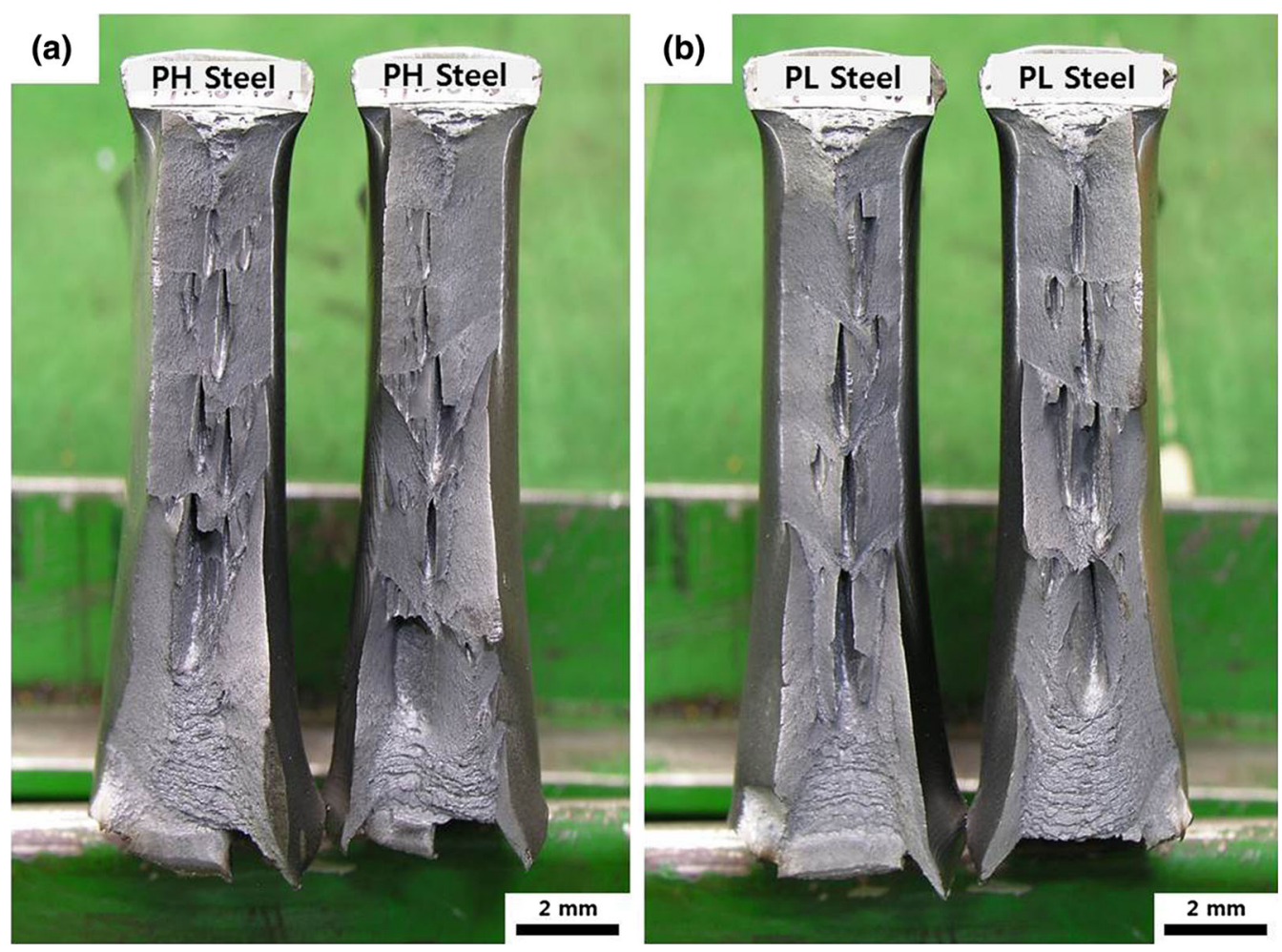

Fig. 9-Low-magnification optical fractographs of the DWTT specimens fractured at $253 \mathrm{~K}\left(-20^{\circ} \mathrm{C}\right)$ of the $(a)$ PH and $(b)$ PL steels.

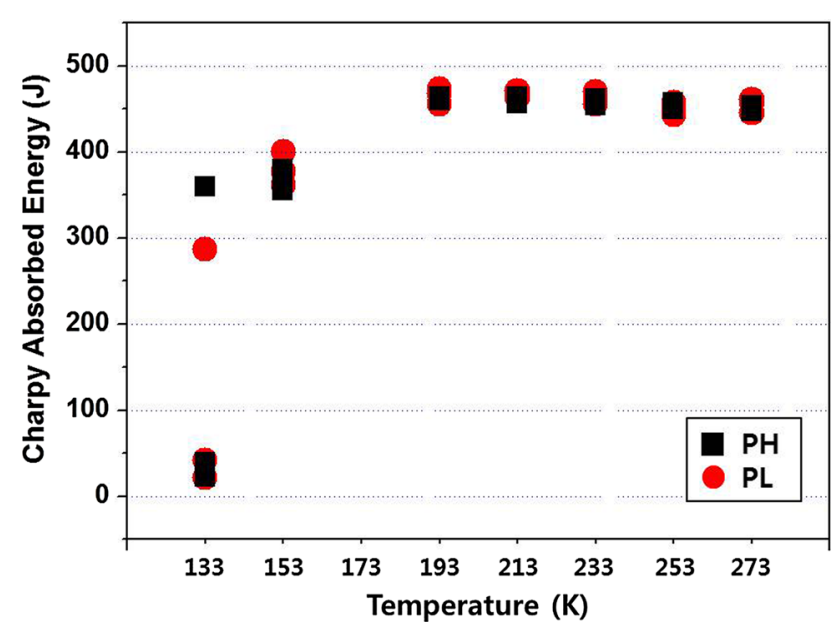

Fig. 10 - Charpy absorbed energy of the PH and PL steels as a function of the test temperature.

Table III. Charpy Impact Properties of the Steels

\begin{tabular}{lccc}
\hline & \multicolumn{3}{c}{ Charpy Absorbed Energy $(\mathrm{J})$} \\
\cline { 2 - 4 } & $273 \mathrm{~K}$ & $153 \mathrm{~K}$ & $133 \mathrm{~K}$ \\
Steels & $\left(0{ }^{\circ} \mathrm{C}\right)$ & $\left(-120^{\circ} \mathrm{C}\right)$ & $\left(-140{ }^{\circ} \mathrm{C}\right)$ \\
\hline PH & $449 \pm 3$ & $340 \pm 14$ & $140 \pm 155$ \\
PL & $455 \pm 7$ & $380 \pm 20$ & $117 \pm 121$ \\
\hline
\end{tabular}

1. The strain-based API X60 linepipe steels consisted mainly of PF or QPF and the volume fraction of $\mathrm{AF}$ increased with the increasing finish cooling temperature, whereas the volume fractions of $\mathrm{BF}$ and martensite and secondary phases decreased.

2. The yield strength, ultimate tensile strength, and yield ratio increased with the increasing thermal aging temperature. The strain hardening rate in the $\mathrm{PH}$ steel decreased rapidly after thermal aging, probably because of the Cottrell atmosphere, whereas the strain hardening rate in the PL steel changed slightly after thermal aging.

3 . The uniform elongation and total elongation decreased with the increasing thermal aging temperature, probably because of the interactions between the carbon atoms and dislocations. The uniform elongation decreased rapidly with the decreasing volume fractions of $\mathrm{BF}$ and martensite and secondary phases.

4. The yield ratio increased with the increasing thermal aging temperature, whereas the strain hardening exponent decreased. The strain hardening exponent of the PL steel decreased rapidly after thermal aging, probably because of the large number of mobile dislocations between PF and BF or martensite or secondary phases.

\section{ACKNOWLEDGMENTS}

This work was supported by the Ministry of Knowledge Economy under a Grant No. 100400-25 and the 2013 Research Fund of University of Ulsan. 


\section{REFERENCES}

1. T. Araki: Atlas for Bainitic Microstructures, ISIJ, Tokyo, 1992, pp. $1-100$.

2. J.Y. Koo, M.J. Luton, N.V. Bangaru, R.A. Petkovic, D.P. Fairchild, C.W. Petersen, H. Asahi, T. Hara, Y. Terada, M. Sugiyama, H. Tamehiro, Y. Komizo, S. Okaguchi, M. Hamada, A. Yamamoto, and I. Takeuchi: Proc. 13th Int. Offshore Polar Eng. Conf., Honolulu, Hawaii, 2003, pp. 10-18.

3. K. Nagai, Y. Shinohara, S. Sakamoto, E. Tsuru, and H. Asahi: Proc. 19th Int. Offshore Polar Eng. Conf., Osaka, Japan, 2009, pp. 56-60.

4. M.W. Hukle, B.D. Newbury, D.B. Lillig, J.J. Regina, and A.M. Horn: Proc. 27th Int. Conf. on Offshore Mech. and Arctic Eng., Estoril, Portugal, 2008, pp. 16-19.

5. G. Shigesato, Y. Shinohara, T. Hara, M. Sugiyama, and H. Asahi: Proc. 16th Int. Offshore Polar Eng. Conf., Lisbon, Portugal, 2007, pp. 2983-87.

6. Y. Shinohara, T. Hara, E. Tsuru, and H. Asahi: Proc. 16th Int. Offshore Polar Eng. Conf., Lisbon, Portugal, 2007, pp. 2949-54.

7. R. Denys: Pipeline Technology Conference, Elsevier, Amsterdam, 2000, vols. I, II, pp. 1-166.

8. US Patent Pub., 2007, No. 20070193666

9. T. Hara, Y. Shinohara, Y. Terada, H. Asahi, and N. Doi: Proc. 19th Int. Offshore Polar Eng. Conf., Osaka, Japan, 2009, pp. 73-79.

10. D.B. Lillig: Proc. 18th Int. Offshore Polar Eng. Conf., Vancouver, Canada, 2008, pp. 1-12.

11. J. Hu, L.-X. Du, J.-J. Wang, C.-R. Gao, T.-Z. Yang, A.-Y. Wang, and R.D.K. Misra: Metall. Mater. Trans. A, 2013, vol. 44A, pp. 4937-47.

12. V. Colla, M. Desanctis, A. Dimatteo, G. Lovicu, and R. Valentini: Metall. Mater. Trans. A, 2011, vol. 41A, pp. 2781-93.
13. S.K. Kim, Y.M. Kim, Y.J. Lim, and N.J. Kim: Proc. 15th Conf. on Mech. Behavior of Mater., Seoul, Korea, 2001, pp. 177-86.

14. G. Krauss and S.W. Thompson: ISIJ Int., 1995, vol. 35, pp. 937-45.

15. S.W. Thompson, D.J. Colvin, and G. Krauss: Metall. Trans. A, 1990, vol. 21A, pp. 1493-1507.

16. H.K.D.H. Bhadeshia: Mater. Sci. Eng. A, 2004, vol. A378, pp. 34 39.

17. T. Hara, Y. Shinohara, Y. Hattori, T. Muraki, and N. Doi: Proc. 21th Int. Offshore Polar Eng. Conf., ISOPE, Hawaii, 2011, pp. $575-80$.

18. Y.M. Kim, S.Y. Shin, H. Lee, B. Hwang, S. Lee, and N.J. Kim: Metall. Mater. Trans. A, 2007, vol. 38A, pp. 1731-42.

19. N. Ishikawa, H. Sueyoshi, and N. Shikanai: Proc. 19th Int. Offshore Polar Eng. Conf., Osaka, Japan, 2009, pp. 43-49.

20. H. Igari, H. Nakanura, and S. Okaguchi: Proc. 21th Int. Offshore Polar Eng. Conf., Hawaii, 2011, pp. 569-74.

21. API Recommended Practice 5L3: American Petroleum Institute, Washington, DC, 1996.

22. W. Oldfield: Curve Fitting Impact Test Data-A Statistical Procedure, ASTM Standardizations News, West Conshohocken, PA, 1975, pp. 24-29.

23. D. Hull and D.J. Bacon: Introduction to Dislocations, 5th ed., Elsevier Ltd., Amsterdam, 2011.

24. C. Capdevila, F.G. Caballero, and C. Garcia de Andres: ISIJ Int., 2003, vol. 42, pp. 894-902.

25. K.W. Andrew: JISI, 1965, vol. 203, pp. 721-27.

26. C.Y. Kung and J.J. Raymond: Metall. Trans. A, 1982, vol. 13A, pp. 328-31.

27. D.P. Koistinen and R.E. Marburger: Acta Metall., 1959, vol. 7, pp. 59-60.

28. Y.M. Kim, S.K. Kim, and N.J. Kim: Mater. Sci. Forum, 2005, vol. 475 , pp. $282-92$. 